\title{
The Influence of General Strikes against Government on Stock Market Behavior
}

\author{
Tomasz Piotr Wisniewski \\ The Open University \\ Faculty of Business and Law \\ Department of Accounting and Finance \\ Walton Hall \\ Milton Keynes, MK7 6AA, UK \\ Phone: +44 1908655020 \\ E-mail: tomasz.wisniewski@open.ac.uk

\section{Brendan John Lambe ${ }^{1}$ \\ De Montfort University} \\ Leicester School of Business \\ The Gateway \\ Leicester, LE1 9BH, UK \\ Tel: +441162013833 \\ E-mail: brendan.lambe@dmu.ac.uk
}

\author{
Alexandra Dias \\ The York Management School \\ University of York \\ Freboys Lane, Heslington \\ York, YO10 5GD, UK \\ Tel: +44 1904325317 \\ E-mail: alexandra.dias@york.ac.uk
}

\footnotetext{
${ }^{1}$ Corresponding author.
} 


\title{
The Influence of General Strikes against Government on Stock Market Behavior
}

\begin{abstract}
Using a sample of 76 countries, this paper examines the impact of major strikes against government and its policies on stock market behavior. An occurrence of a general strike is detrimental to the value of equities, as documented by the ceteris paribus $5.77 \%$ fall in dollar-denominated stock market indices of the affected countries. This event is also accompanied by a statistically significant increase in risk, as measured by the standard deviation of returns and Value-at-Risk metrics. Taken together, these results imply that general strikes have serious ramifications for stock market investors.
\end{abstract}

Keywords: General strikes, stock prices, political effects

JEL Codes: G12, J52 


\section{Introduction}

Extant academic literature recognizes that developments on the political stage may be reflected in stock market valuations and volatility. A number of authors traced the link between equity pricing and important events, such as issuances of policy-related communiqués (Wisniewski and Moro, 2014), international political crises and wars (Berkman et al. 2011), revolutions (Acemoglu et al, 2014), coup d'états (Bautista, 2003; Dube et al., 2011), or assassinations of key public figures (Zussman and Zussman, 2006). Surprisingly, the existing scholarship neglects to elucidate the impact of another important event, which has the capacity to generate political tension and create economic uncertainty. When discontent within the workforce grows to critical levels, it materializes in the form of a general strike which transcends regional and firm-level considerations. Such strike action would typically involve mass walkouts of workers across a multitude of employers organized in protest against government impositions.

A number of authors point out that the rate with which strikes against individual employers occur in Western Europe has decreased sharply over the last couple of decades, while at the same time the incidence of general strikes has risen (Kelly and Hamann, 2010; Vandeale, 2011; Gall, 2013). The distinction between the economic and general strikes is important, as the latter mobilizes workers to mount pressure on the government, rather than employers. While the industrial relations literature abounds with rationalizations behind economic strikes, the theoretical frameworks that have been developed in this field are not well equipped to deal with politically motivated mass walkouts (Hamann, Johnston and Kelly, 2013a). To compound this problem, academic scholarship on general strikes is currently in an incipient state. Considering that the national work stoppages have potentially far-reaching economic and societal consequences, further inquiry into this subject area is warranted. 
The research that has been done to date focused primarily on the incidence of general strikes and the motivations that drive the unions to stage opposition to government plans and reforms (Vandeale, 2011; Gall, 2013; Hamann, Johnston and Kelly, 2013a). A number of papers considered the determinants of union success, which can be measured according to the concessions granted by the government (Johnson, 2000; Hamann, Johnston and Kelly, 2013b; Nowak and Gallas, 2014). Implications for policy makers were further highlighted by Hamann, Johnston and Kelly (2013c) who documented the vote share losses of incumbents in the presence of general strikes. This is unsurprising considering the substantial efforts exerted by the unions to engage voters, generate news stories and expose the alleged incompetency of the government. To counter the resultant electoral losses, a country's leadership that faces popular protests is more likely to align fiscal policy with the election cycle. More specifically, Klomp and de Haan (2013) showed that affected governments increase their spending and deficits in the pre-election year in order to temporarily stimulate the economy and, as a consequence, boost popular support.

While some clarity may have emerged with respect to the outcomes encountered by workers and governments, the literature remains silent with regards to the ramifications faced by employers. It is this void in the body of knowledge that our paper intends to fill. Even if the general strikes are not strictly directed against companies, their value may be adversely affected for several reasons. First, the unproductive periods impose costs in terms of lower levels of output and profits. Although general strikes are typically short in duration, the large number of employees involved has a bearing on the total number of days not worked (Gall, 2013). Second, such manifestations of popular dissent signal to the market the workforce's frustration with the government and its policies. In the case where policy-makers are responsive to the demands being made, a general strike may also signal the weakening position of capital providers and other sources of power within the productive process. Corporations may also be forced into a 
position of carrying the burden of government concessions and the costs of social pacts that are agreed in the aftermath of a general strike. Third, in instances where the future response of the government is not known with certainty, additional investment risk is created. Such risk will raise the time-varying discount rates leading to lower stock valuations and increased market volatility. Fourth, conceding to workers' demands may lead to a deterioration in a government's financial position, which will exert upward pressure on bond yields and discount rates. This, in turn, would further aggravate the falls in stock prices.

Our findings in this study reflect the abovementioned considerations. Through investigating a large sample spanning an array of countries, we demonstrate a valuation impact that is both statistically and economically significant. Since the magnitude of the fall in stock prices coinciding with the occurrence of a general strike is substantial, investors should pay particular attention to this type of event. Furthermore, we record significant increases in stock index return volatility and Value-at-Risk ${ }^{2}$ in the year of the event, which could be indicative of the policy uncertainty that arises alongside mass strike action. Such findings should be brought into consideration by those on both sides of the divide who are engaged in the collective bargaining process.

Market vulnerability around times of mass strike action could be particularly distressing to shareholders who are not internationally diversified. The problem is of concern not only to frontline investors but extends to a wider swathe of the population invested in the market through pension funds. It is neither in the interest of trade unions nor governments to adversely affect the value of retirement portfolios. For this reason, both parties should seek alternative resolutions that do not involve walkouts. This means that in order to avoid costly economic frictions, governments should be wary of situations which may inflame worker indignation.

\footnotetext{
${ }^{2}$ Value-at-Risk ( $\mathrm{VaR}$ ) measures the expected value of loss that will be surpassed with a small probability during a specific period.
} 
Similarly, trade unions should consider the full welfare implications for their members before staging a mass protest.

The remainder of the paper is organized as follows. The next section reviews the literature on general strikes and considers their implications for policy uncertainty and stock prices. Section III describes our data sources and variable definitions. Basic summary statistics and correlation analysis are also provided. Section IV presents estimates for our return and risk models and propounds an interpretation of our findings. This is followed by a battery of robustness checks and additional results, which are presented in Section V. The paper ends with conclusions and suggestions for future research.

\section{General Strikes, Political Uncertainty and Stock Prices}

Strikes against employers, which typically relate to wage negotiations, are an integral part of industrial relations. They impose a burden on the affected companies by introducing output disruptions, triggering disgruntlement among the workforce, causing losses in market share to competitors, attracting negative publicity and creating a bill for post-strike overtime payments. A large body of literature examined the detrimental influence that strikes exert on shareholder wealth from the perspective of individual firms (Neumann, 1980; Becker and Olson, 1986; De Fusco and Fuess, 1991; Kramer and Vasconellos, 1996; Kramer and Hyclack, 2002), affected industries (Dinardo and Hallock, 2002), or both (Persons, 1995). The estimates of equity value lost by the companies which experience workforce strikes vary depending on the sample and time frame considered. These range from a fraction of a percentage point in the days immediately surrounding the announcement date (Neumann, 1980; Kramer and Hyclack,

2002) to over 4 percent for longer event windows (Becker and Olson, 1986). Stock prices tend to predict strike occurrences (Neumann, 1980; Becker and Olson 1986) and can rebound partially after a settlement between the workforce and management is reached (Kramer and 
Vasconcellous, 1996). A small positive response to a walkout is registered by unaffected competitors (De Fusco and Fuess, 1991; Kramer and Hylack, 2002) and a spillover effect can occur in closely related industries (Persons, 1995). Peress (2014) notes that newspaper strikes are of particular importance to stock markets, as they decrease trading activity and the dispersion of returns. Myriad theories have been developed to clarify why labor disputes arise and the most influential of these are described in Kramer and Hyclak (2002).

While the aforementioned theories and the findings of empirical studies illuminate the causes and consequences of labor disputes within companies, they cannot shed much light on general strikes. This is because instead of targeting issues related to a single employer, general strikes mobilize the broader workforce to protest against current or planned governmental action. More specifically, we define general strikes as a large number of workers employed by more than one company coming together with the intent to oppose government policies or its authority. Kelly and Hamann (2010) rightly note that despite the increasing frequency of general strikes in Western Europe, the literature on this topic is rather scant. Theirs is the first attempt to theorize the motivations underlying this phenomenon. According to their framework, general strikes are more likely to occur whenever the government is right-leaning or when it tries to intervene in labor markets, wages or the welfare system. The likelihood is also greater in nations that protect the right to strike through their constitution and when governments exclude unions from consultations on social reforms.

An anti-government nationwide walkout may be of concern to capital markets for several reasons. First, there is the non-trivial output loss associated with en-masse work stoppages. Second, investors may fear that, once subjected to the pressure of public opinion and trade unions, the government may be more inclined to pass legislation that benefits workers at the expense of capital owners. Third, and perhaps most importantly, a general strike is a manifestation of political tensions that permeate the whole of society and may be perceived as 
a popular vote of no confidence in the government. Facing the lack of societal support may force the government to reconsider its plans, which in turn introduces a great deal of policy uncertainty.

Several authors have already examined the relationship between the level of political risk and the pricing of securities. Their findings serve to illuminate and guide our investigation. Bittlingmayer (1998) focused on a turbulent period in German history, which ranged from 1880 to 1940 and encapsulates World War I, insurrection, revolution, hyperinflation and extreme political turmoil. He concludes that political uncertainty caused output slumps and increased stock return volatility. In a similar vein, Bautista (2003) who examined the case of the Philippines discovered that the military coup attempts which occurred there in the 1980s induced pronounced stock market fluctuations.

Attempts to measure political risk by means of continuous indices have also been made. Baker et al. (2013) constructed a measure for the United States which amalgamates the frequency with which newspapers refer to policy uncertainty, the degree to which forecasters disagree about the future consumer price index and government purchases, as well as information on expiring tax code provisions. In their paper, Pástor and Veronesi (2013) show that this index is positively associated with realized and implied stock market volatility. Antonakakis et al. (2013) confirm this finding and additionally show that stock prices are depressed in times of heightened policy uncertainty. This relationship can be easily rationalized in a framework which allows for time-varying risk-adjusted discount rates. Another useful version of a continuous index to reflect uncertainty has been developed by Political Risk Services and is disseminated in their International Country Risk Guide dataset. It provides aggregated survey responses regarding a wide range of political risk characteristics and covers a large number of countries. Diamonte et al. (1996) and Bilson et al. (2002) who employed this index demonstrate that changes in the political risk rating are instantaneously reflected in stock 
prices, and that in the long-term, investors can expect to be compensated for being exposed to political uncertainty.

The review of existing literature presented above shapes our a priori expectations regarding the relationship between general strikes and stock markets. With the clearly signaled lack of popular support for government policies and the increased discount rates that accompany heightened political risk, one would expect the timing of mass anti-government protests to coincide with negative returns. In addition, following the observations made in the previous studies reviewed here, it can be anticipated that the magnitude of stock market fluctuations will increase in times of politically-motivated tumult. One should be able to detect this phenomenon by examining the evolution of return volatility and Value-at-Risk over time.

\section{Data}

Our empirical analysis relies on capitalization-weighted country-level stock market indices constructed by MSCI. At the time of writing, 77 country indices were available for developed, emerging, frontier and standalone markets. We downloaded this data from Thomson Reuters Datastream for a period ranging from 1970 to 2014. The returns used here are continuously compounded and denominated in US dollars in order to facilitate international comparisons. In one set of regressions we choose the annual index return as our dependent variable. However, the computation of our risk proxies requires the use of data with a higher sampling frequency. More specifically, Volatility is defined as the annualized standard deviation of daily returns within a given calendar year, while VaR is an annualized Value-atRisk measure estimated through historical simulation based on daily returns. Our VaR assumes a 95\% probability and an investment of one US dollar. The Value-at-Risk approach is commonly viewed as a superior means by which downside risk can be appropriately estimated, particularly in cases where return distribution is skewed and leptokurtic. 
The information on our main variable of interest General_Strikes is sourced from the Cross-National Time-Series Data Archive 2015. The variable is defined as the number of strikes against governmental authority or policies involving at least 1,000 workers from a minimum of two employers. The sampling frequency is annual and the data covers all of the countries for which an MSCI index is available, with the notable exception of Hong Kong. This means that our analysis can be performed on an unbalanced panel of 76 countries and 1,733 country-years. A complete list of nations is provided in Appendix A. The number of observations and nations is reduced in regressions with additional control variables due to the problem of missing values.

One could be tempted to hypothesize that general strikes are merely a symptom of poor macroeconomic fundamentals. To invalidate this assertion and demonstrate that their occurrence carries additional information relevant to the markets, we need to take into account the prevailing macroeconomic conditions. To this end, we collected data on the logged GDP level, GDP growth, inflation in consumer prices and unemployment rates. In addition, information on central government debt, its final consumption expenditure and stock market capitalization (all expressed as a percentage of GDP) has been gathered. The source of the abovementioned data is World Development Indicators, which is hosted on UK Data Service portal.

Furthermore, Kelly and Hamann (2010) allude to the possibility that general strikes may be a by-product of the political environment, so in order to cleanly disentangle their impact from that of other political developments, we need to introduce additional controls. We source data on electoral and political constellations from the Database of Political Institutions 2015, a dataset that was initially constructed by the World Bank and subsequently updated by the InterAmerican Development Bank. Since warmongering has been previously shown to have a detrimental effect on equity prices (Rigobon and Sack, 2005; Wolfers and Zitzewitz, 2009; 
Berkman et al., 2011), we consider a dummy indicating country-years in which the Chief Executive was a military officer. By 'Chief Executive' we mean a prime minister in parliamentary systems or a president in presidential systems. Secondly, there has been a debate amongst scholars as to whether the political orientation of the executive holds ramifications for the distribution of stock returns (see Wisniewski (2016) for a literature review on this topic). In the analysis that follows we consider dummies for leftist and centrist executives, with the right-wing orientation serving as a benchmark. Since the results reported in Pantzalis et al. (2000) and Bialkowski et al. (2008) suggest that the first two moments of return distribution could be affected by the occurrence of national elections, we create an executive election dummy to capture such effects. The political instability indicators in the form of the number of public demonstrations and situations threatening regime collapse were sourced from CrossNational Time-Series Data Archive. Lastly, we retrieved measures for lack of corruption and law and order from the International Country Risk Guide to proxy for the integrity of the political system.

[Table I about here]

[Table II about here]

Table I catalogues all of our variables with their corresponding definitions, while Table II presents summary statistics. The continuously compounded stock index return was on average $5.22 \%$ per annum, with an accompanying annualized within-year return volatility of $24.03 \%$ and annualized VaR of 37.16 cents. Economies grew by $3.84 \%$ per annum and had an unemployment rate of $8.49 \%$. The mean of inflation appears high and is affected by hyperinflationary periods in Israel, Peru, Ukraine and Kazakhstan during the 80s and 90s and in the CEE countries during the communist rule and immediately after its fall. Interestingly, all of these cases are automatically eliminated from our regression estimation, as MSCI did not provide stock market data for the hyperinflationary periods in these particular countries. The 
government debt averages at $55.92 \%$ of GDP, while the final government consumption expenditure as a proportion of GDP has a mean of $17.59 \%$. Market capitalization of domestic firms listed on local stock exchanges exceeded half of the value of goods and services produced annually.

Among Chief Executives, $10.57 \%$ were military officers, $42.40 \%$ were leftist and $12.81 \%$ were centrists. The mean of the Election variable appears to be small, however, one needs to remember that some countries like Qatar or China do not hold elections, while the communist states in CEE existing prior to 1989 were undemocratic. Furthermore, in some countries (e.g. Czech Republic, Italy, or Germany) the prime minister or chancellor is nominated/appointed by the president. The Database of Political Institutions does not classify such an event as an executive election. Crises threatening the collapse of government occurs on average every five years, while demonstrations, statistically speaking, happen once per annum. The means of Lack_of_Corruption and Law_and_Order are comparable within our sample.

\section{[Table III about here]}

Table III reports Pearson correlation coefficients between our dependent and explanatory variables. Most importantly, we can infer that the occurrence of general strikes coincides with significantly lower returns and elevated levels of volatility risk and VaR. However, before reaching definite conclusions, one needs to remember that correlation analysis is simplistic in the sense that it does not simultaneously control for other factors that can affect risk and reward. Consequently, a multivariate regression analysis is required to confirm this finding. 


\section{Results}

For the purposes of our empirical modeling we employ a two-way fixed effect panel. This methodological choice is motivated by two observations. Firstly, the Hausman (1978) test rejects the null hypothesis of the orthogonality of the random effects and the regressors in a large proportion of our specifications. This, in turn, means that a random effect specification will not be able to provide consistent estimates. Secondly, the hypothesis that both crosssectional and time period dummies are jointly insignificant is strongly rejected in all of our models. Conceptually, the cross-sectional fixed effects account for the time-invariant differences between countries, while the time fixed effects capture global trends in the dependent variable. In other words, our specification allows us to isolate the country-specific component of variation in the regressor. Lastly, we use the Arellano (1987) approach to estimate heteroscedasticity and autocorrelation consistent standard errors. Since our data has $N$ $=76$ countries and $T=45$ years, we assume that $N$ is sufficiently large to allow us to adopt the Arellano (1987) method. This approach estimates the heteroscedasticity and autocorrelation consistent standard errors assuming that the errors are independently distributed across countries but allowing for within country heteroscedasticity and serial correlation of unknown forms.

Our two-way fixed effect panel regression equation can be written down as follows:

$$
\begin{aligned}
& \text { Return }_{i, t}=c_{i}+\lambda_{t}+\beta_{1} \text { General_Strikes }{ }_{i, t}+\sum_{j=1}^{7} \gamma_{j}{\text { Economic_Indicator }(j)_{i, t}}+ \\
& \sum_{k=1}^{8} \delta_{k} \text { Political_Indicator }(k)_{i, t}+\varepsilon_{i, t}
\end{aligned}
$$

where $c_{i}$ and $\lambda_{t}$ denote fixed effects for country $i$ and year $t$, General_Strikes is the main explanatory variable of interest in our model, the set of economic indicators consists of $\{$ GDP_Growth, Inflation, Unemployment, Debt_to_GDP, Government_Consumption, Capitalization_to_GDP and Economy_Size $\}$, the political indicators include $\{$ Military, Left, 
Centre, Election, Government_Crisis, Demonstrations, Lack_of_Corruption, Law_and_Order $\}$, while $\varepsilon_{i, t}$ is an error term. In most specifications we impose parameter restrictions, setting some of the coefficient to equal zero. To investigate other aspects of market behavior we also estimate regressions analogous to [1] with the exception that we substitute the dependent variable with either Volatility or VaR.

Although including a wide range of controls in equation [1] allows us to mitigate the omitted variable bias, it also reduces the number of observations available for estimation. This is because each of the indicators has missing values, which leads to a significantly reduced sample when a numerous controls are considered. To address this problem, we have designed a formalized procedure to eliminate redundant independent variables. More specifically, we endeavor to achieve a parsimonious specification, which is arrived at by iteratively dropping a regressor with the highest $p$-value until every explanatory factor in the regression is statistically significant. We operate on the assumption that the parsimonious model is the most appropriate, as it reaches a balance between reducing omitted variable bias and maximizing the number of observations necessary for precise estimation.

\section{[Insert Table IV about here]}

Table IV reports estimates of panel models that explain the variation in stock index returns. Depending on the specification, a general strike leads to a change in share valuations ranging in magnitude from $-3.48 \%$ to $-5.77 \%$. The latter figure represents an estimate from our preferred parsimonious model in which only statistically significant controls are used. This huge decline implies that the impact of general strikes extends beyond simple output losses. Even if we were to assume that the entire population of a country participates in a general strike, these losses would be equivalent to around $0.4 \%$ of GDP per day and would not necessarily imply any declines in future productivity. This suggests that stock market investors 
apply a much broader interpretation to this type of event. Perhaps the discount rates increase due to the perceived escalation of policy uncertainty, resulting in lower valuations. The occurrence of a general strike could be also viewed as either a manifestation of the workforce's dissent or a signal that government policies are misguided. However, due to the difficulties inherent in measuring such phenomena, these assertions would be difficult to validate empirically.

Several of the control variables also prove to exert an influence on stock valuations. There is some weak evidence to suggest that prices are propelled by real activity, which is in line with the findings of several earlier papers (see for instance Chen et al., 1986 and Nasseh and Strauss, 2000). The positive coefficient on the unemployment rate may at first blush appear counterintuitive but can be easily rationalized within the Tobin's q theory (Tobin 1969, 1998). High stock market returns are likely to raise the Tobin's q, defined as the market valuation of capital assets to their replacement value, which incentivizes companies to make additional capital investments. Since new capital can be used to procure technologies that may be labor saving, a negative relationship between returns and unemployment is not entirely unexpected. Furthermore, stock market capitalization to GDP ratio has a strong and positive bearing on returns. This is consistent with the results of Levine and Zervos (1996) who demonstrate that equity market development stimulates long-term economic growth, possibly through the channels of improved resource allocation, securement of a better regimen of corporate control and an enhancement of risk management opportunities.

Specifications (3) to (5) indicate that actions of political executives with military credentials appear to erode equity values. This observed phenomenon could arise due to a higher perceived probability of military conflict. The devastating effect that wars have on shareholders' wealth has been extensively documented in the literature (Rigobon and Sack, 2005; Wolfers and Zitzewitz, 2009; Wisniewski, 2009; Omar et al., 2017). Berkman et al. 
(2001) estimate that in the complete absence of international political crises and wars, the annual global stock returns would be $3.6 \%$ higher. With regard to political orientation, our dataset allows us to partition the political spectrum into three segments. All of the previous papers in the field applied a simple left-wing / right-wing categorization, without any allowance for centrist executives (for a list of these papers see Wisniewski (2016)). Our results are similar to those reported in Gottschalk and Bohl (2006) who fail to detect any significant return differences between left- and right-leaning leaders in a panel of 15 countries. We also note that investors are not significantly compensated for taking on election risk, which to a large extent confirms the earlier findings of Bialkowski et al. (2008). As also indicated by our econometric results, circumstances which can be construed as government crisis are not conducive to generating healthy capital gains on equities. However, a political context characterized by demonstrations, corruption and the crumbling of law and order does not have strong explanatory power in our regressions.

\section{[Table V about here]}

Table V reports our results regarding the volatility of stock market indices. This volatility is of great importance, as it affects the magnitude of systematic risk of every listed stock. Interestingly, general strikes coincide with a significant increase in the standard deviation of index returns. Depending on the specification, one strike leads to a ceteris paribus increase of about 1.19 to 1.87 percentage points. This means that investors face inferior Sharpe ratios due to a simultaneous decrease in reward and an exacerbated riskiness. When examining the coefficients on our control variables, we are able to reinforce the earlier findings of Schwert (1989) that return volatility is higher in times of recession and we observe a similar tendency for economies struggling with high inflation. Weak evidence emerges to suggest that government consumption acts as a financial stabilizer, while larger economies tend to experience a lesser degree of fluctuation. There also appears to be robust evidence that market 
movements are amplified when left-wing executives are in power. Our results cohere with the conclusions of Bialkowski et al. (2008) and Kelly et al. (2016) who argue that stock market riskiness is elevated during periods of national elections. Moreover, circumstances which threaten the current regime significantly contribute to gyrations in the markets. The slight indication that corruption can reduce stock market volatility is consistent with previously reported results by Lau et al. (2013) who argue that corporate bribery of state representatives is an effective tool in reducing government policy uncertainty.

\section{[Table VI about here]}

Table VI presents estimation results for models focusing on Value-at-Risk. Broadly speaking, these results are congruent with our abovementioned findings for volatility. From the parsimonious model, one can infer that the occurrence of a general strike increases the annualized VaR by about 2.21 cents for every dollar invested. This metric is elevated during recessionary and inflationary periods but appears smaller in sizable economies and somewhat moderated by government expenditure. The nature of the political executive is also influential in the regressions, with left-wing and military oriented leaderships magnifying downside risk. An increase of about 3.7 cents is observed in election years and in periods of left-wing rule. There is some indication that VaR is greater when the political system is plagued with episodes of crises and that companies can pay-off government officials to reduce the policy change risk. We note at this stage that all of the models reported in this paper perform well in terms of the goodness of fit and the null hypothesis that the regressors are jointly insignificant is always strongly rejected. 


\section{Further Considerations}

\subsection{Alternative Specifications}

In an attempt to win popular support, political parties cater for the needs of their respective electorates. Parties on the left of the political spectrum tend to draw their support from workers, while the right typically protects the interests of capital holders (Hibbs, 1977). Consequently, it may be reasonable to assume that leftist incumbents are more likely to yield to the demands of organized labor. In the context of our investigation, it would be interesting to verify whether the orientation of the political executive relates to a set of outcomes from general strikes. To investigate this idea, we interact three dummies representing government orientation with our General_Strikes indicator and use these terms as explanatory variables in our return regression (see model (1) in Table VII). The regression specification is a variant of the parsimonious model, which we consider to be the most appropriate. Everything else held constant, the fall in stock market valuations is largest under leftist (-7.52\%) and smallest under right-wing administrations $(-3.55 \%)$. While the difference appears economically significant, the null hypothesis that the regression coefficient is equal across the three orientations specified cannot be rejected at the conventional significance levels $(F$-statistic $=0.9009, p$-value $=$ 0.4067).

[Table VII about here]

During election years, incumbents will prioritize image management through avoiding events which may resonate negatively throughout the society. Consequently, governments may be more inclined to reach an agreement with the unions that do not favor the interests of capital. To test whether this assertion is supported by our data, we rerun the parsimonious return model where the General_Strikes variable is interacted with dummies for election and non-election years. Specification (2) in Table VII demonstrates that, ceteris paribus, the losses to capital owners arising from mass strike action against the government are higher in years when voters 
cast their ballots (-7.84\%), as opposed to times when they do not (-5.41\%). However, an $F$-test for the equality of coefficients on the interaction terms fails to reject the null hypothesis $(F$ statistic $=1.4529, p$-value $=0.2284$.

Finally, we inspect if the observed drop in the stock market indices can be attributable to lagged stock returns rather than general strikes. To this end, we consider a simple dynamic panel model (see specification (3) in Table VII). We fit a two-way fixed effects dynamic panel model using the Arellano and Bond (1991) generalised method of moments (GMM) approach. Further lags of the stock index returns are used as GMM instruments and General_Strikes is used as a normal instrument. From fitting the model we observe that general strikes retain their statistical and economic significance, even after lagged returns are introduced as an explanatory variable. This finding clearly attests to the robustness of our results. Considering that our data has relatively low sampling frequency, the negative autoregressive coefficient in our model corroborates the story of mean reversion in stock prices over long horizons which was put forward by Poterba and Summers (1988).

\subsection{Event Study}

The data on general strikes from the Cross-National Time-Series Data Archive used in this study has an annual sampling frequency and is constructed based on newspaper reports. We have managed to obtain links to these reports from the data vendor for the 2011-2015 period. Based on this information, we were able to precisely identify the starting dates for 89 general strikes. This permitted us to analyze the domestic stock market behavior during the days immediately surrounding the strike action. Narrowing the focus from an annual period to a much shorter event window significantly ameliorates the problem of confounding variables. To operationalize the analysis, we employed standard event study methodology commonly used in the finance literature (Brown and Warner, 1980; 1985). 
In what follows, we concentrate our attention on a period starting 10 working days prior to the general strike and ending 10 working days thereafter. This span defines our $(-10,10)$ event window centered upon the day on which mass labor action begins (Day 0). In cases where the onset of a strike coincided with a weekend or bank holiday, Day 0 was assumed to be the first trading day that followed. Over the abovementioned event window, we analyze the abnormal behavior of returns, which are the defined as the difference between observed returns and those that would have materialized had the general strike not occurred. The latter return is a purely theoretical construct which cannot be observed directly and is approximated using a statistical benchmark model. In our calculations, we decided to utilize a market model, which we estimate over a 250-trading day window immediately preceding the event window. The model can be expressed as follows:

$$
R_{i, t}=\hat{\alpha}+\hat{\beta} R_{m, t}+\varepsilon_{i, t}, \quad t \in(-260,-11)
$$

where $R_{i, t}$ is the MSCI stock index return for the country in which general strike $i$ occurred, $R_{m, t}$ is the MSCI world stock market index return denominated in US dollars and $\varepsilon_{i, t}$ is the regression residual. We subsequently focus on the event window and proceed to calculate abnormal returns $(A R \mathrm{~s})$ based on the parameter estimates of the market model:

$$
A R_{i, t}=R_{i, t}-\left(\hat{\alpha}+\hat{\beta} R_{m, t}\right), \quad t \in(-10,10)
$$

These abnormal returns are averaged across all $N$ events and cumulated over time to create the cumulative abnormal return $(C A R)$ :

$$
C A R_{t}=\sum_{j=-10}^{t} \sum_{i=1}^{N} \frac{A R_{i, j}}{N}, \quad t \in(-10,10)
$$

These CARs represent the returns attributable entirely to general strikes episodes and their statistical significance is assessed using a test described in Kothari and Warner (2007).

[Figure I about here] 
Figure 1 plots the evolution of CARs in the event window. As general strikes are often pre-announced, it is unsurprising that the onset of stock market declines materializes prior to Day 0. This unfavourable trend appears to continue long after the outbreak of protests, depressing equity valuations even further. The magnitude of CAR in the window considered here is $-1.77 \%$, which significantly differs from zero in the statistical sense (t-statistic $=-2.25)$. While the estimate of this fall is substantial, it is somewhat more conservative than that implied by our panel regressions. Two explanations may be offered for this observation. Firstly, the pricing ramifications of general strikes may extend beyond the short 21-day window, as the impact exerted on the political environment may be long-lasting and uncertain at first. Secondly, general strikes happening after 2011 that were the subject of this event study analysis may not be representative of our panel data sample that started in 1970. Nowak and Gallas (2014) note that the mass strikes against austerity that followed the 2008 financial crisis were largely unsuccessful, while those that took place prior to the crisis frequently managed to secure government concessions (Hamann, Johnston and Kelly, 2013b).

\subsection{Bootstrap Approach}

Our methodological approach implemented thus far relied heavily on estimating panel regressions. For the purposes of a robustness check, we abandon this mode of inquiry and instead implement a bootstrap matched-pair analysis with a counterfactual. To start with, we note that in our sample we have 201 country-years which have witnessed at least one general strike and for which stock return data was available. The average annual return for these observations is $-4.30 \%$. We then proceed to draw at random 201 observations from the subsample of country-years that experienced no general strike and compute the corresponding mean return. This step is repeated 10,000 times in order to generate an empirical distribution for the mean return conditional on no strike. This distribution (depicted in Figure 2) appears to be centered on a value of $6.44 \%$; a figure substantially higher than the strike return average. In 
fact, only one of our 10,000 iterations produced a mean below $-4.30 \%$, which in turn implies that the bootstrap $p$-value for the null hypothesis that the general strike country-years come from the same distribution as the rest of the observations is 0.0001 . The strong rejection of the null is consistent with the main story outlined in our paper.

[Figure II about here]

\subsection{Government Bond Yields}

Prior literature documented a link between political uncertainty and the probability of rescheduling and defaulting on government debt (Balkan, 1992; Cuadra and Sapienza, 2008). In an efficient market the risk attached to the probability of an interrupted payment will be reflected in bond yields. General strikes as a facet of political uncertainty could, therefore, affect government-issued fixed income securities. To investigate this point, we have collected data on the long-term government bond yields for our sample countries from the International Financial Statistics database compiled by the International Monetary Fund. Table VIII reports estimates from two-way fixed effect regressions linking general strikes to yields. In model (1) we perform the estimation in the absence of controls, whilst in the second model we include all the regressors collected earlier. The final parsimonious specification (3) excluded all insignificant variables using the iterative procedure described in Section IV. Our General_Strikes variable bears a positive coefficient and is statistically significant in all regressions. In the parsimoniously specified model, the magnitude of increase is 0.43 basis points per strike. This prima facie may not appear large, however, considering the amounts raised by governments in the bond market, the nominal value of this effect could be substantial. As an illustration, we 
would like to note that the value of central government debt across OECD member countries was approximately equal to their GDP in $2015 .^{3}$

[Table VIII about here]

\section{Conclusions}

There is a rich literature in industrial relations focusing on strikes against employers and the ramifications these have for the market capitalization of affected companies (see for instance Neumann, 1980; Kramer and Vasconellos, 1996; Kramer and Hyclack, 2002). In comparison, the body of work on general strikes, while illuminating, is less voluminous. Within this scholarship, attention is directed towards the unionized workers (Johnson, 2000; Hamann, Johnston and Kelly, 2013b) or governments (Hamann, Johnston and Kelly, 2013c; Klomp and De Haan, 2013). Ours is a paper which views the instances of general strikes from a different angle, namely that of capital providers.

Specifically, we show that general strikes hold grave ramifications for stock markets. The losses to shareholders holding a passive portfolio invested locally are estimated in our preferred model to be in the order of $5.77 \%$ in the year of the event. This loss does not appear to be attributable to other factors in the macroeconomic, financial and political arena, as we comprehensively control for these. The fact that our result is not a consequence of confounding influences is further reaffirmed by the event study analysis which shows the presence of negative returns in the days immediately surrounding strike action. The estimated price declines are too substantial to be entirely justified by the output forgone due to the walkout. Apparently, investors look at this event from a much broader perspective. Such a manifestation of discontent within the workforce can exacerbate policy uncertainty and, in turn, lead to an increase in discount rates. This rationalization could imply significant price declines and

\footnotetext{
${ }^{3}$ Data sourced from World Development Indicators.
} 
increases in market riskiness. Interestingly, during the years in which general strikes take place, substantial aggrandizement in risk is clearly observable. Annualized standard deviation of index returns goes up by 1.19 percentage points, while the annualized Value-at-Risk jumps by 2.21 cents for every dollar invested. When we examine government long-term bond yields during the period of a labor standoff, we find a statistically significant increase, reflecting possible fiscal considerations of concessions.

Clearly, these documented tendencies are problematic from the investors' point of view. General strikes appear to reduce the reward to capital holders, while simultaneously heightening the risks involved. Furthermore, governments should bear in mind the additional negative externalities which their tense relations with organized labor could generate. Since a large proportion of the electorate may be affected through their shareholdings, the penalties to incumbents may ultimately be borne out at the ballot box. Since governments are further penalized by increased costs of servicing public debt, they should engage in a more comprehensive cost-benefit analysis of countering the discontent of organized labor. Our findings are also relevant to trade union leaders who are contemplating a mass walkout against government policies. Since negative stock returns can deplete pension pots, the costs of general strikes to workers need to be accounted for accurately. Clearly, the real costs of striking surpasses the total of wages forgone.

While there are many theories related to firm-level labor disputes, theorizing about general strikes is in a rather embryonic state. Although some attempts to address this issue have been made by Kelly and Hamann (2010), fellow researchers should still endeavor to formulate conceptual frameworks explaining this phenomenon. Only after we gain a full understanding of the causes underlying general strikes, will we be able to construct reliable predictive models. Such models could be potentially useful to those who trade actively in the stock market. 


\section{Appendix A}

List of countries included in our empirical study categorized using the MSCI convention.

Developed Markets: Canada, US, Austria, Belgium, Denmark, Finland, France, Germany, Ireland, Israel, Italy, Netherlands, Norway, Portugal, Spain, Sweden, Switzerland, UK, Australia, Japan, New Zealand, Singapore

Emerging Markets: Brazil, Chile, Colombia, Mexico, Peru, Czech Republic, Egypt, Greece, Hungary, Poland, Qatar, Russia, South Africa, Turkey, UAE, China, Indonesia, Korea, Malaysia, Philippines, Taiwan, Thailand

Frontier Markets: Argentina, Bulgaria, Croatia, Estonia, Lithuania, Kazakhstan, Romania, Serbia, Slovenia, Kenya, Mauritius, Morocco, Nigeria, Tunisia, Bahrain, Jordan, Kuwait, Oman, Bangladesh, Pakistan, Sri Lanka, Vietnam

Standalone Markets: Saudi Arabia, Jamaica, Trinidad \& Tobago, Bosnia and Herzegovina, Ukraine, Botswana, Ghana, Zimbabwe, Palestine, Lebanon 


\section{References}

Acemoglu, D., Hassan, T.A., \& Tahoun, A. (2014). The power of the street: Evidence from Egypt's Arab Spring. NBER Working Paper no. 20665, available at http://www.nber.org/papers/w20665, last accessed Sep 21 ${ }^{\text {st }}, 2016$.

Antonakakis, N., Chatziantoniou, I., \& Filis, G. (2013). Dynamic co-movements of stock market returns, implied volatility and policy uncertainty. Economics Letters 120(1), pp. 87-92.

Arellano, M. (1987). Computing robust standard errors for within-groups estimators. Oxford Bulletin of Economics and Statistics 49(4), pp.431-434.

Arellano, M. \& Bond, S. (1991). Some tests of specification for panel data: Monte Carlo evidence and an application to employment equations. The Review of Economic Studies, 58(2), pp.277-297.

Baker, S.R., Bloom, N., \& Davis, S.J. (2013). Measuring economic policy uncertainty. SSRN working paper, available at: http://ssrn.com/abstract=2198490, last accessed Oct 18, 2015.

Balkan, E.M. (1992). Political instability, country risk and probability of default. Applied Economics, 24(9), pp. 999-1008.

Bautista, C.C. (2003). Stock market volatility in the Philippines. Applied Economics Letters 10(5), pp. 315-318.

Becker, B.E. \& Olson, C.A. (1986). The impact of strikes on shareholder equity. Industrial and Labor Relations Review 39(3), pp. 425-438.

Berkman, H., Jacobsen, B., \& Lee, J.B. (2011). Time-varying rare disaster risk and stock returns. Journal of Financial Economics 101(2), pp. 313-332.

Białkowski, J., Gottschalk, K., \& Wisniewski, T.P. (2008). Stock market volatility around national elections. Journal of Banking \& Finance 32(9), pp. 1941-1953.

Bilson, C.M., Brailsford, T.J., \& Hooper, V.C. (2002). The explanatory power of political risk in emerging markets. International Review of Financial Analysis 11(1), pp. 1-27.

Bittlingmayer, G. (1998). Output, stock volatility, and political uncertainty in a natural experiment: Germany, 1880-1940. Journal of Finance 53(6), pp. 2243-2257.

Bohl, M.T., \& Gottschalk, K. (2006). International evidence on the Democrat premium and the presidential cycle effect. The North American Journal of Economics and Finance 17(2), pp. 107-120.

Brown, S.J. \& Warner, J.B. (1980). Measuring security price performance. Journal of Financial Economics, 8(3), pp. 205-258.

Brown, S.J. \& Warner, J.B. (1985). Using daily stock returns: the case of event studies. Journal of Financial Economics, 14(1), pp. 3-31.

Chen, N. F., Roll, R., \& Ross, S. A. (1986). Economic forces and the stock market. Journal of Business 59(3), pp. 383-403.

Cuadra, G. \& Sapriza, H. (2008). Sovereign default, interest rates and political uncertainty in emerging markets. Journal of International Economics, 76(1), pp. 78-88. 
De Fusco, R.A. \& Fuess, S.M. Jr. (1991). The effect of airline strikes on struck and nonstruck carriers. Industrial and Labor Relations Review 44(2), pp. 324-333.

Diamonte, R.L., Liew, J.M., \& Stevens, R.L. (1996). Political risk in emerging and developed markets. Financial Analysts Journal 52(3), May/June, pp. 71-76.

Dinardo, J. and Hallock, K.F. (2002). When unions "mattered": the impact of strikes on financial markets, 1925-1937. Industrial and Labor Relations Review 55(2), pp. 219-233.

Dube, A., Kaplan, E., \& Naidu, S. (2011). Coups, Corporation and classified information. Quarterly Journal of Economics 126(3), pp. 1375-1409.

Gall, G. (2013). Quiescence continued? Recent strike activity in nine Western European economies. Economic and Industrial Democracy, 34(4), pp. 667-691.

Hamann, K., Johnston, A. \& Kelly, J. (2013a). Unions against governments: Explaining general strikes in Western Europe, 1980-2006. Comparative Political Studies, 46(9), pp. 1030-1057.

Hamann, K., Johnston, A. \& Kelly, J. (2013b). Striking concessions from governments: The success of general strikes in Western Europe, 1980-2009. Comparative Politics, 46(1), pp. 23-41.

Hamann, K., Johnston, A. \& Kelly, J. (2013c). The Electoral Consequences of General Strikes in Western Europe (2013). APSA 2013 Annual Meeting Paper; American Political Science Association 2013 Annual Meeting, available at https://ssrn.com/abstract=2303140, last accessed: Aug $8^{\text {th }}, 2018$.

Hausman, J. A. (1978). Specification tests in econometrics. Econometrica 46(6), pp. 12511271.

Hibbs, D.A. (1977). Political parties and macroeconomic policy. American Political Science Review, 71(4), pp. 1467-1487.

Johnson, V. (2000). The cultural foundation of resources, the resource foundation of political cultures: An explanation for the outcomes of two general strikes. Politics \& Society, 28(3), pp. 331-365.

Kelly, B., Pástor, L., \& Veronesi, P. (2016). The price of political uncertainty: Theory and evidence from the option market. Journal of Finance 71(5), pp. 2417-2480.

Kelly, J. \& Hamann, K. (2010). General strikes in Western Europe, 1980-2008. Paper for the European Regional Congress of the International Industry Relations Association, Copenhagen, 28 June- 1 July 2010, available at: http://faos.ku.dk/pdf/iirakongres2010/track4/28.pdf, last accessed: March 31 ${ }^{\text {st }}, 2016$.

Klomp, J. \& de Haan, J. (2013). Popular protest and political budget cycles: A panel data analysis. Economics Letters, 120(3), pp. 516-520.

Kothari, S.P. \& Warner, J.B. (2007). Econometrics of event studies. In: Eckbo, Espen, B. (Eds.), Handbook of Corporate Finance: Empirical Corporate Finance. Elsevier/ NorthHolland, Amsterdam.

Kramer, J.K. \& Hyclak, T. (2002). Why strikes occur: Evidence from the capital markets. Industrial Relations 41(1), pp. 80-93.

Kramer, J.K. \& Vasconcellos, G.M. (1996). The economic effect of strikes on the shareholders of nonstruck competitors. Industrial Relations and Labor Review 49(2), pp. 213-222. 
Lau, C.K.M., Demir, E. \& Bilgin, M.H. (2013). Experience-based corporate corruption and stock market volatility: Evidence from emerging markets. Emerging Markets Review, 17, pp. 1-13.

Levine, R. \& Zervos, S. (1996). Stock market development and long-run growth. The World Bank Economic Review, 10(2), pp. 323-339.

Nasseh, A., \& Strauss, J. (2000). Stock prices and domestic and international macroeconomic activity: a cointegration approach. The Quarterly Review of Economics and Finance 40(2), pp. 229-245.

Neumann, G.R. (1980). The predictability of strikes: Evidence from the stock market. Industrial and Labor Relations Review 33(4), pp. 525-535.

Nowak, J. \& Gallas, A. (2014). Mass strikes against austerity in Western Europe-A strategic assessment. Global Labour Journal, 5(3), pp. 306-21.

Omar, A.M.A., Wisniewski, T.P., \& Nolte, S. (2017). Diversifying the risk of war and crossborder political crisis, Energy Economics, 64, pp. 494-510.

Pantzalis, C., Stangeland, D.A., \& Turtle, H.J. (2000). Political elections and the resolution of uncertainty: the international evidence. Journal of Banking \& Finance 24(10), pp. 15751604.

Pástor, L'., \& Veronesi, P. (2013). Political uncertainty and risk premia. Journal of Financial Economics 110(3), pp. 520-545.

Persons, O.S. (1995). The effects of automobile strikes on the stock value of steel suppliers. Industrial and Labor Relations Review 49(1), pp. 78-87.

Peress, J. (2014). The media and the diffusion of information in financial markets: Evidence from newspaper strikes. Journal of Finance 69(5), pp. 2007-2043.

Poterba, J.M. \& Summers, L.H. (1988). Mean reversion in stock prices: Evidence and implications. Journal of Financial Economics, 22(1), pp. 27-59.

Rigobon, R., \& Sack, B. (2005). The effects of war risk on US financial markets. Journal of Banking \& Finance 29(7), pp. 1769-1789.

Schwert, G.W. (1989). Why does stock market volatility change over time? Journal of Finance 44(5), pp. 1115-1153.

Tobin, J. (1969). A general equilibrium approach to monetary theory. Journal of Money, Credit and Banking, 1(1), pp. 15-29.

Tobin, J. (1998). Money, Credit and Capital, McGraw-Hill, New York.

Vandaele, K. (2011). Sustaining or Abandoning 'Social Peace'? Strike Development and Trends in Europe Since the 1990s. ETUI Working Paper 2011.05, available at https://ssrn.com/abstract=2221798, last accessed Aug 8 ${ }^{\text {th }}, 2018$.

Wisniewski, T.P. (2009). Can political factors explain the behaviour of stock prices beyond the standard present value models? Applied Financial Economics 19(23), pp. 1873-1884.

Wisniewski, T.P. (2016). Is there a link between politics and stock returns? A literature survey. International Review of Financial Analysis 47, pp. 15-23.

Wisniewski, T.P., \& Moro, A. (2014). When EU leaders speak, the markets listen. European Accounting Review 23(4), pp. 519-551. 
Wolfers, J., \& Zitzewitz, E. (2009). Using markets to inform policy: The case of the Iraq war. Economica 76(302), pp. 225-250.

Zussman, A., \& Zussman, N. (2006). Assassinations: Evaluating the effectiveness of an Israeli counterterrorism policy using stock market data. The Journal of Economic Perspectives 20(2), pp. 193-206. 
Table I

Variable Definitions

\begin{tabular}{|c|c|}
\hline Variable Name & Definition \\
\hline Return & $\begin{array}{l}\text { Continuously compounded US dollar-denominated return on the country's MSCI } \\
\text { capitalization-weighted stock market index computed for a given calendar year. }\end{array}$ \\
\hline Volatility & $\begin{array}{l}\text { Standard deviation of daily continuously compounded returns on } \mathrm{MSCl} \text { stock } \\
\text { market index computed for a given country-year. This standard deviation was } \\
\text { annualized on the assumption that there are } 252 \text { trading days in a calendar year. }\end{array}$ \\
\hline VaR & $\begin{array}{l}5^{\text {th }} \text { percentile of historical daily return distribution within a given year times } \\
\text { minus one times the square root of } 252 \text {. }\end{array}$ \\
\hline General_Strikes & $\begin{array}{l}\text { Number of strikes against government policies or authority involving more than } \\
1,000 \text { workers from more than one employer. }\end{array}$ \\
\hline GDP_Growth & Annual percentage growth rate in real GDP. \\
\hline Inflation & Annual percentage change in consumer price index. \\
\hline Unemployment & Harmonized ILO estimate of unemployment rate. \\
\hline Debt_to_GDP & Central government debt (\% of GDP). \\
\hline Government_Consumption & $\begin{array}{l}\text { General government final consumption expenditure scaled by GDP (derived } \\
\text { variable). }\end{array}$ \\
\hline Capitalization_to_GDP & Market capitalization of domestic firms listed on the stock exchange (\% of GDP). \\
\hline Economy_Size & Natural logarithm of GDP (constant 2010 US dollars). \\
\hline Military & $\begin{array}{l}\text { A dummy variable taking a value of } 1 \text { when the political executive is a military } \\
\text { officer and } 0 \text { otherwise. }\end{array}$ \\
\hline Left & $\begin{array}{l}\text { A dummy variable indicating country-years in which the party orientation with } \\
\text { respect to economic policy can be best defined as communist, socialist, social } \\
\text { democratic, or left-wing. }\end{array}$ \\
\hline Centre & $\begin{array}{l}\text { A dummy variable indicating country-years in which the ruling party has a } \\
\text { centrist ideology. }\end{array}$ \\
\hline
\end{tabular}

Source

Source

Datastream

Own calculations

Own calculations

Cross-National Time-Series Data Archive 2015

World Development Indicators

World Development Indicators

World Development Indicators

World Development Indicators

World Development Indicators

World Development Indicators

World Development Indicators

Database of Political Institutions 2015

Database of Political Institutions 2015

Database of Political Institutions 2015 
Election

Government_Crisis

Demonstrations

Lack_of_Corruption

Law_and_Order
A dummy variable taking a value of 1 for country-years in which executive election took place and 0 otherwise.

Number of situations threatening the collapse of the current regime (excluding revolts).

Number of public demonstrations of 100 people or more countering government or its policies (excluding those anti-foreign in nature).

A variable gauging the extent of corruption within political system, measured on a six-point scale. High values indicate a system with greater integrity.

An aggregate measure of the strength and impartiality of the legal system and popular adherence to the law.
Database of Political Institutions 2015

Cross-National Time-Series Data

Archive

Cross-National Time-Series Data Archive

International Country Risk Guide

International Country Risk Guide 
Table II

\section{Summary Statistics}

This table contains basic summary statistics for the variables used in the study. These variables have been defined in Table I. The second column reports the number of observations available for each indicator. In the third and fourth column we display arithmetic averages and sample standard deviations. The last three statistics shown in the table are the $25^{\text {th }}, 50^{\text {th }}$ a $75^{\text {th }}$ percentile of the variable distribution.

\begin{tabular}{|c|c|c|c|c|c|c|}
\hline Variable Name & No. Obs. & Mean & $\begin{array}{l}\text { Standard } \\
\text { Deviation }\end{array}$ & $25^{\text {th }}$ Percentile & Median & $75^{\text {th }}$ Percentile \\
\hline Return & 1753 & 0.0522 & 0.3611 & -0.1368 & 0.0801 & 0.2603 \\
\hline Volatility & 1719 & 0.2403 & 0.1249 & 0.1622 & 0.2106 & 0.2847 \\
\hline $\operatorname{VaR}$ & 1719 & 0.3716 & 0.1965 & 0.2439 & 0.3182 & 0.4448 \\
\hline General_Strikes & 3096 & 0.1899 & 0.6907 & 0.0000 & 0.0000 & 0.0000 \\
\hline GDP_Growth & 2889 & 0.0384 & 0.0515 & 0.0165 & 0.0381 & 0.0604 \\
\hline Inflation & 2668 & 0.2514 & 2.1448 & 0.0253 & 0.0566 & 0.1127 \\
\hline Unemployment & 1702 & 0.0849 & 0.0518 & 0.0483 & 0.0760 & 0.1040 \\
\hline Debt_to_GDP & 1058 & 0.5592 & 0.8652 & 0.2820 & 0.4792 & 0.6868 \\
\hline Government_Consumption & 2551 & 0.1759 & 0.0668 & 0.1253 & 0.1828 & 0.2168 \\
\hline Capitalization_to_GDP & 1548 & 0.5388 & 0.5031 & 0.1894 & 0.3781 & 0.7312 \\
\hline Economy_Size & 2928 & 26.6448 & 53.6559 & 24.4231 & 25.7336 & 26.7278 \\
\hline Military & 2809 & 0.1057 & 0.3075 & 0.0000 & 0.0000 & 0.0000 \\
\hline Left & 1842 & 0.4240 & 0.4943 & 0.0000 & 0.0000 & 1.0000 \\
\hline Centre & 1842 & 0.1281 & 0.3343 & 0.0000 & 0.0000 & 0.0000 \\
\hline Election & 2821 & 0.0737 & 0.2614 & 0.0000 & 0.0000 & 0.0000 \\
\hline Government_Crisis & 3096 & 0.1957 & 0.5379 & 0.0000 & 0.0000 & 0.0000 \\
\hline Demonstrations & 3096 & 1.0203 & 3.0751 & 0.0000 & 0.0000 & 1.0000 \\
\hline Lack_of_Corruption & 1361 & 4.4730 & 1.3855 & 3.5000 & 5.0000 & 6.0000 \\
\hline Law_and_Order & 1361 & 4.2922 & 1.2870 & 3.5000 & 4.5000 & 5.0000 \\
\hline
\end{tabular}


Table III

\section{Correlations between Dependent and Explanatory Variables}

This table reports Pearson correlation coefficients with the corresponding significance levels. For definitions of the variables please see Table I. ${ }^{* * *},{ }^{* *},{ }^{*}$ denote statistical significance at the $1 \%, 5 \%$ and $10 \%$ level, respectively.

\begin{tabular}{llll}
\hline Variable Name & Return & Volatility & VaR \\
\hline General_Strikes & $-0.0890^{* * *}$ & $0.0950^{* * *}$ & $0.0967^{* * *}$ \\
GDP_Growth & $0.0724^{* * *}$ & $-0.1787^{* * *}$ & $-0.1690^{* * *}$ \\
Inflation & -0.0112 & $0.2222^{* * *}$ & $0.2325^{* * *}$ \\
Unemployment & $0.0646^{* *}$ & 0.0079 & -0.0017 \\
Debt_to_GDP & 0.0143 & $-0.0764^{* *}$ & $-0.0639^{*}$ \\
Government_Consumption & 0.0351 & $-0.1343^{* * *}$ & $-0.1208^{* * *}$ \\
Capitalization_to_GDP & $0.1372^{* * *}$ & $-0.1699^{* * *}$ & $-0.1583^{* * *}$ \\
Economy_Size & 0.0097 & 0.0158 & $0.0718^{* * *}$ \\
Military & 0.0137 & $0.0655^{* * *}$ & 0.0315 \\
Left & 0.0071 & -0.0243 & -0.0066 \\
Centre & -0.0247 & $0.1080^{* * *}$ & $0.0886^{* * *}$ \\
Election & 0.0119 & $0.0997^{* * *}$ & $0.0908^{* * *}$ \\
Government_Crisis & $-0.0776^{* * *}$ & $0.1582^{* * *}$ & $0.1359^{* * *}$ \\
Demonstrations & $-0.0845^{* * *}$ & 0.0350 & $0.0424^{*}$ \\
Lack_of_Corruption & -0.0177 & $-0.1070^{* * *}$ & $-0.0551^{* * *}$ \\
Law_and_Order & -0.0161 & $-0.1437^{* * *}$ & $-0.1040^{* * *}$ \\
\hline
\end{tabular}




\section{Table IV}

\section{Determinants of Stock Index Returns}

The dependent variable in each of the two-way fixed effect panel regressions presented below is the continuously compounded dollar-denominated return on $\mathrm{MSCl}$ country stock market index in a given calendar year. Definitions of the explanatory variables can be found in Table I. Coefficient standard errors are reported in parentheses. The five specifications presented below differ with respect to the inclusion of macroeconomic and political controls. The F-statistic and the corresponding probability are for the null hypothesis that the regressors included in a given model are jointly irrelevant to the process being modelled. ${ }^{* * *},{ }^{* *},{ }^{*}$ denote statistical significance at the $1 \%, 5 \%$ and $10 \%$ level, respectively.

\begin{tabular}{|c|c|c|c|c|c|}
\hline & (1) & (2) & (3) & (4) & (5) \\
\hline General_Strikes & $\begin{array}{l}-0.0348^{* *} \\
(0.0085)\end{array}$ & $\begin{array}{l}-0.0408^{* *} \\
(0.0159)\end{array}$ & $\begin{array}{l}-0.0437^{* * *} \\
(0.0169)\end{array}$ & $\begin{array}{l}-0.0411^{* *} \\
(0.0178)\end{array}$ & $\begin{array}{l}-0.0577^{* * *} \\
(0.0114)\end{array}$ \\
\hline GDP_Growth & & $\begin{array}{c}1.0638^{*} \\
(0.5913)\end{array}$ & & $\begin{array}{c}0.3779 \\
(0.6998)\end{array}$ & \\
\hline Inflation & & $\begin{array}{c}0.0016 \\
(0.1234)\end{array}$ & & $\begin{array}{c}0.3712 \\
(0.8218)\end{array}$ & \\
\hline Unemployment & & $\begin{array}{c}1.3499^{* *} \\
(0.6036)\end{array}$ & & $\begin{array}{c}1.2776^{* *} \\
(0.5239)\end{array}$ & $\begin{array}{l}1.9888^{* * *} \\
(0.5152)\end{array}$ \\
\hline Debt_to_GDP & & $\begin{array}{c}0.0569 \\
(0.1145)\end{array}$ & & $\begin{array}{c}0.0941 \\
(0.0948)\end{array}$ & \\
\hline Government_Consumption & & $\begin{array}{c}0.9692 \\
(1.0330)\end{array}$ & & $\begin{array}{c}2.0478 \\
(1.8566)\end{array}$ & \\
\hline Capitalization_to_GDP & & $\begin{array}{l}0.1977^{* * *} \\
(0.0675)\end{array}$ & & $\begin{array}{l}0.3954^{* * *} \\
(0.1020)\end{array}$ & $\begin{array}{l}0.2239^{* * *} \\
(0.0468)\end{array}$ \\
\hline Left & & & $\begin{array}{c}0.0034 \\
(0.0284)\end{array}$ & $\begin{array}{l}-0.0280 \\
(0.0337)\end{array}$ & \\
\hline Centre & & & -0.0599 & -0.0881 & \\
\hline
\end{tabular}




\begin{tabular}{|c|c|c|c|c|c|}
\hline & & & $(0.0375)$ & $(0.0585)$ & \\
\hline Election & & & $\begin{array}{l}-0.0375 \\
(0.0279)\end{array}$ & $\begin{array}{l}-0.0188 \\
(0.0328)\end{array}$ & \\
\hline Government_Crisis & & & $\begin{array}{l}-0.0468 \\
(0.0306)\end{array}$ & $\begin{array}{l}-0.0638 \\
(0.0542)\end{array}$ & $\begin{array}{l}-0.0533^{* *} \\
(0.0259)\end{array}$ \\
\hline Demonstrations & & & $\begin{array}{c}0.0019 \\
(0.0023)\end{array}$ & $\begin{array}{c}0.0013 \\
(0.0029)\end{array}$ & \\
\hline Law_and_Order & & & $\begin{array}{c}0.0096 \\
(0.0192)\end{array}$ & $\begin{array}{l}-0.0203 \\
(0.0257)\end{array}$ & \\
\hline No. Obs. & 1733 & 662 & 765 & 416 & 961 \\
\hline Adj. R-squared & $44.6252 \%$ & $58.2214 \%$ & $54.5670 \%$ & $66.5319 \%$ & $55.9388 \%$ \\
\hline F-statistic & 12.6315 & 12.2335 & 12.6152 & 12.6196 & 14.1052 \\
\hline
\end{tabular}




\section{Table V}

\section{Models of Stock Market Index Volatility}

The two-way fixed effect panel regressions presented in the table link annualized stock market index return volatility to the number of general strikes and additional controls. All variable definitions are given in Table I. Standard errors of the coefficients are shown in parenthesis. The specifications included in the table differ in the extent to which they incorporate the macroeconomic and political controls. The F-statistic is for the hypothesis that the regressors are jointly unable to explain the variation in the dependent variable. ${ }^{* * *},{ }^{* *},{ }^{*}$ denote statistical significance at the $1 \%, 5 \%$ and $10 \%$ level, respectively.

\begin{tabular}{|c|c|c|c|c|c|}
\hline & (1) & (2) & (3) & (4) & (5) \\
\hline General_Strikes & $\begin{array}{c}0.0158^{* *} \\
(0.0063)\end{array}$ & $\begin{array}{l}0.0159^{* * *} \\
(0.0059)\end{array}$ & $\begin{array}{l}0.0187^{* * *} \\
(0.0035)\end{array}$ & $\begin{array}{l}0.0146^{* * *} \\
(0.0052)\end{array}$ & $\begin{array}{l}0.0119^{* * *} \\
(0.0031)\end{array}$ \\
\hline GDP_Growth & & $\begin{array}{l}-0.8336^{* *} \\
(0.3296)\end{array}$ & & $\begin{array}{l}-0.3011 \\
(0.2833)\end{array}$ & $\begin{array}{l}-0.4937^{* *} \\
(0.2277)\end{array}$ \\
\hline Inflation & & $\begin{array}{l}0.3103^{* * *} \\
(0.1166)\end{array}$ & & $\begin{array}{c}0.4415^{* *} \\
(0.1919)\end{array}$ & \\
\hline Unemployment & & $\begin{array}{l}-0.0546 \\
(0.2238)\end{array}$ & & $\begin{array}{l}-0.0364 \\
(0.2568)\end{array}$ & \\
\hline Debt_to_GDP & & $\begin{array}{c}0.0091 \\
(0.0457)\end{array}$ & & $\begin{array}{c}0.0214 \\
(0.0402)\end{array}$ & \\
\hline Government_Consumption & & $\begin{array}{l}-1.1007^{* * *} \\
(0.3839)\end{array}$ & & $\begin{array}{l}-0.5871 \\
(0.5018)\end{array}$ & \\
\hline Capitalization_to_GDP & & $\begin{array}{c}0.0108 \\
(0.0202)\end{array}$ & & $\begin{array}{l}-0.0253 \\
(0.0305)\end{array}$ & \\
\hline Economy_Size & & $\begin{array}{l}-0.1705^{* * *} \\
(0.0418)\end{array}$ & & $\begin{array}{l}-0.1727^{* *} \\
(0.0823)\end{array}$ & $\begin{array}{l}-0.1420^{* * *} \\
(0.0357)\end{array}$ \\
\hline Military & & & $\begin{array}{c}0.0267 \\
(0.0309)\end{array}$ & $\begin{array}{c}0.0308 \\
(0.0300)\end{array}$ & $\begin{array}{c}0.0340^{*} \\
(0.0181)\end{array}$ \\
\hline Left & & & $\begin{array}{c}0.0194^{* *} \\
(0.0092)\end{array}$ & $\begin{array}{c}0.0227^{* *} \\
(0.0096)\end{array}$ & $\begin{array}{c}0.0231^{* *} \\
(0.0093)\end{array}$ \\
\hline
\end{tabular}




\begin{tabular}{|c|c|c|c|c|c|}
\hline Centre & & & $\begin{array}{c}0.0093 \\
(0.0171)\end{array}$ & $\begin{array}{c}0.0231 \\
(0.0258)\end{array}$ & \\
\hline Election & & & $\begin{array}{l}0.0225^{* * *} \\
(0.0067)\end{array}$ & $\begin{array}{c}0.0248^{* *} \\
(0.0104)\end{array}$ & $\begin{array}{c}0.0183^{* * *} \\
(0.0068)\end{array}$ \\
\hline Government_Crisis & & & $\begin{array}{l}0.0246^{* * *} \\
(0.0090)\end{array}$ & $\begin{array}{c}0.0096 \\
(0.0097)\end{array}$ & $\begin{array}{c}0.0156^{* *} \\
(0.0073)\end{array}$ \\
\hline Demonstrations & & & $\begin{array}{c}0.0001 \\
(0.0007)\end{array}$ & $\begin{array}{l}-0.0007 \\
(0.0007)\end{array}$ & \\
\hline Lack_of_Corruption & & & $\begin{array}{c}0.0150^{*} \\
(0.0086)\end{array}$ & $\begin{array}{c}0.0149 \\
(0.0106)\end{array}$ & $\begin{array}{c}0.0188^{* *} \\
(0.0084)\end{array}$ \\
\hline Law_and_Order & & & $\begin{array}{l}-0.0002 \\
(0.0109)\end{array}$ & $\begin{array}{c}0.0085 \\
(0.0097)\end{array}$ & \\
\hline No. Obs. & 1701 & 662 & 765 & 416 & 743 \\
\hline Adj. R-squared & $53.4701 \%$ & $74.9445 \%$ & $64.3499 \%$ & $77.6850 \%$ & $66.9516 \%$ \\
\hline F-statistic & 17.5556 & 25.1115 & 18.4563 & 21.3484 & 20.5220 \\
\hline Prob(F-stat) & 0.0000 & 0.0000 & 0.0000 & 0.0000 & 0.0000 \\
\hline
\end{tabular}




\section{Table VI}

\section{Regressions for Value at Risk}

The panel regressions presented in this table link an annualized Value at Risk (VaR) measure to a range of explanatory variables. For variable definitions please refer to Table I. Figures in parenthesis denote standard errors. The specifications below are two-way fixed effect panel regression differing in the extent to which they incorporate political and macroeconomic control variables. The F-statistic is for the null hypothesis that the regressors are jointly unable to explain the variation in the dependent variable. ${ }^{* * *},{ }^{* *},{ }^{*}$ denote statistical significance at the $1 \%, 5 \%$ and $10 \%$ level, respectively.

\begin{tabular}{|c|c|c|c|c|c|}
\hline & (1) & (2) & (3) & (4) & (5) \\
\hline General_Strikes & $\begin{array}{c}0.0250^{* *} \\
(0.0097)\end{array}$ & $\begin{array}{c}0.0280^{* * *} \\
(0.0103)\end{array}$ & $\begin{array}{l}0.0296^{* * *} \\
(0.0062)\end{array}$ & $\begin{array}{l}0.0258^{* * *} \\
(0.0097)\end{array}$ & $\begin{array}{c}0.0221^{* * *} \\
(0.0051)\end{array}$ \\
\hline GDP_Growth & & $\begin{array}{l}-1.1817^{* *} \\
(0.4815)\end{array}$ & & $\begin{array}{l}-0.4356 \\
(0.4682)\end{array}$ & $\begin{array}{l}-0.5878^{*} \\
(0.3082)\end{array}$ \\
\hline Inflation & & $\begin{array}{l}0.5444^{* * *} \\
(0.1249)\end{array}$ & & $\begin{array}{c}0.7453^{* *} \\
(0.3348)\end{array}$ & \\
\hline Unemployment & & $\begin{array}{l}-0.1126 \\
(0.3620)\end{array}$ & & $\begin{array}{l}-0.1498 \\
(0.4354)\end{array}$ & \\
\hline Debt_to_GDP & & $\begin{array}{l}-0.0145 \\
(0.0711)\end{array}$ & & $\begin{array}{c}0.0241 \\
(0.0728)\end{array}$ & \\
\hline Government_Consumption & & $\begin{array}{l}-1.3753^{* *} \\
(0.5789)\end{array}$ & & $\begin{array}{l}-0.7970 \\
(0.8311)\end{array}$ & \\
\hline Capitalization_to_GDP & & $\begin{array}{c}0.0113 \\
(0.0352)\end{array}$ & & $\begin{array}{l}-0.0665 \\
(0.0547)\end{array}$ & \\
\hline Economy_Size & & $\begin{array}{l}-0.2662^{* * *} \\
(0.0714)\end{array}$ & & $\begin{array}{l}-0.3211^{* *} \\
(0.1493)\end{array}$ & $\begin{array}{l}-0.2035^{* * *} \\
(0.0545)\end{array}$ \\
\hline Military & & & $\begin{array}{c}0.0823 \\
(0.0691)\end{array}$ & $\begin{array}{c}0.1099^{* *} \\
(0.0540)\end{array}$ & $\begin{array}{c}0.0894^{*} \\
(0.0519)\end{array}$ \\
\hline Left & & & $\begin{array}{c}0.0328^{* *} \\
(0.0158)\end{array}$ & $\begin{array}{c}0.0410^{* *} \\
(0.0188)\end{array}$ & $\begin{array}{c}0.0366^{* *} \\
(0.0150)\end{array}$ \\
\hline Centre & & & $\begin{array}{c}0.0105 \\
(0.0288)\end{array}$ & $\begin{array}{c}0.0410 \\
(0.0438)\end{array}$ & \\
\hline
\end{tabular}




$\begin{array}{ccc}0.0414^{* * *} & 0.0495^{* * *} & 0.0365^{* * *} \\ (0.0126) & (0.0179) & (0.0133) \\ 0.0248^{* *} & 0.0216 & \\ (0.0120) & (0.0187) & \\ 0.0002 & -0.0010 & \\ (0.0010) & (0.0012) & 0.0313^{* * *} \\ 0.0276^{* *} & 0.0190 & (0.0117) \\ (0.0125) & (0.0190) & \\ 0.0029 & 0.0162 & 743 \\ (0.0168) & (0.0165) & 72.9115 \% \\ 765 & 416 & 27.2786 \\ 71.4083 \% & 76.4298 \% & 0.0000 \\ 25.1532 & 19.9535 & \\ 0.0000 & 0.0000 & \end{array}$

Government_Crisis

Demonstrations

Lack_of_Corruption

Law and Order

662

$60.6100 \%$

$74.1877 \%$

0.0000

0.0000 


\section{Table VII}

\section{Alternative Specifications of the Return Regression}

Contained in the table below are two modified versions of the baseline parsimonious return regression and a dynamic model specification. Definitions of all variables can be found in Table I. The numbers shown within parentheses are standard errors. The first two models are estimated using a two-way fixed effects panel approach with heteroscedasticity and autocorrelation consistent standard errors. Regression (1) includes interactive terms that multiply the dummies for the political orientation of the government with the General_Strikes variable. Model (2) measures the ceteris paribus impact of general strikes on stock returns conditional on the presence of national political executive elections. The last specification reported is a two-way fixed effect dynamic panel model estimated using the Arellano and Bond (1991) generalised method of moments approach. The Wald test is testing the hypothesis that the coefficients on the two explanatory variables reported in column (3) of the table are equal to zero. ${ }^{* * *},{ }^{* *},{ }^{*}$ denote statistical significance at the $1 \%, 5 \%$ and $10 \%$ level, respectively.

\begin{tabular}{|c|c|c|c|}
\hline & (1) & (2) & (3) \\
\hline General_Strikes $\times$ Left & $\begin{array}{l}-0.0752^{* * *} \\
(0.0175)\end{array}$ & & \\
\hline General_Strikes $\times$ Centre & $\begin{array}{l}-0.0572 \\
(0.0688)\end{array}$ & & \\
\hline General_Strikes $\times$ Right & $\begin{array}{l}-0.0355^{* *} \\
(0.0178)\end{array}$ & & \\
\hline General_Strikes $\times$ Election & & $\begin{array}{l}-0.0785^{* * *} \\
(0.0251)\end{array}$ & \\
\hline General_Strikes $\times(1$-Election $)$ & & $\begin{array}{l}-0.0541^{* * *} \\
(0.0094)\end{array}$ & \\
\hline General_Strikes & & & $\begin{array}{l}-0.0406^{* * *} \\
(0.0102)\end{array}$ \\
\hline Return_Lagged & & & $\begin{array}{l}-0.0987^{*} \\
(0.0492)\end{array}$ \\
\hline Unemployment & $\begin{array}{l}1.7585^{* * *} \\
(0.5318)\end{array}$ & $\begin{array}{l}1.9739^{* * *} \\
(0.5003)\end{array}$ & \\
\hline Capitalization_to_GDP & $\begin{array}{c}0.2946^{* * *} \\
(0.0590)\end{array}$ & $\begin{array}{l}0.2229^{* * *} \\
(0.0467)\end{array}$ & \\
\hline Military & $\begin{array}{l}-0.3006^{* *} \\
(0.1260)\end{array}$ & $\begin{array}{l}-0.1615^{* *} \\
(0.0677)\end{array}$ & \\
\hline Government_Crisis & $\begin{array}{l}-0.0600 \\
(0.0424)\end{array}$ & $\begin{array}{l}-0.0538^{* *} \\
(0.0261)\end{array}$ & \\
\hline No. Obs. & 719 & 961 & 1508 \\
\hline Adj. R-squared & $57.8355 \%$ & $55.9132 \%$ & \\
\hline F-statistic & 13.7903 & 13.9524 & \\
\hline Prob(F-stat) & 0.0000 & 0.0000 & \\
\hline Wald Test & & & 16.1835 \\
\hline Prob(Wald test) & & & 0.0003 \\
\hline
\end{tabular}




\section{Table VIII}

\section{Determinants of Long Term Government Bond Yields}

This table reports results for three regression models where long term government bond yields act as a dependent variable. The indicators used in these models are defined in Table I. Standard errors are shown in parentheses. A two-way fixed effect panel estimation with heteroscedasticity and autocorrelation consistent standard errors is employed. The three specifications examine the link between bond yields and general strikes, without controls (1), with a full set of controls (2) and with statistically significant regressors only (3). Displayed below are ${ }^{* * *},{ }^{* *},{ }^{*}$ denote statistical significance at the $1 \%, 5 \%$ and $10 \%$ level, respectively.

\begin{tabular}{|c|c|c|c|}
\hline & (1) & (2) & (3) \\
\hline General_Strikes & $\begin{array}{l}0.0077^{* * *} \\
(0.0029)\end{array}$ & $\begin{array}{c}0.0027^{* *} \\
(0.0013)\end{array}$ & $\begin{array}{l}0.0043^{* *} \\
(0.0019)\end{array}$ \\
\hline GDP_Growth & & $\begin{array}{l}-0.2320^{* * *} \\
(0.0725)\end{array}$ & $\begin{array}{l}-0.2103^{* * *} \\
(0.0631)\end{array}$ \\
\hline Inflation & & $\begin{array}{c}0.3718^{* * *} \\
(0.1300)\end{array}$ & $\begin{array}{c}0.4757^{* * *} \\
(0.1007)\end{array}$ \\
\hline Unemployment & & $\begin{array}{c}0.0860 \\
(0.0537)\end{array}$ & $\begin{array}{l}0.1824^{* * *} \\
(0.0353)\end{array}$ \\
\hline Debt_to_GDP & & $\begin{array}{l}0.0188^{* * *} \\
(0.0068)\end{array}$ & \\
\hline Government_Consumption & & $\begin{array}{l}-0.1437 \\
(0.1160)\end{array}$ & \\
\hline Capitalization_to_GDP & & $\begin{array}{l}-0.0006 \\
(0.0036)\end{array}$ & \\
\hline Economy_Size & & $\begin{array}{l}-0.0455^{* *} \\
(0.0211)\end{array}$ & \\
\hline Military & & $\begin{array}{c}0.0141^{* * *} \\
(0.0054)\end{array}$ & \\
\hline Left & & $\begin{array}{c}0.0008 \\
(0.0015)\end{array}$ & \\
\hline Centre & & $\begin{array}{c}0.0060^{* *} \\
(0.0028)\end{array}$ & \\
\hline Election & & $\begin{array}{c}0.0029 \\
(0.0034)\end{array}$ & \\
\hline Government_Crisis & & $\begin{array}{c}0.0027 \\
(0.0018)\end{array}$ & \\
\hline Demonstrations & & $\begin{array}{l}-0.0004^{* * *} \\
(0.0002)\end{array}$ & \\
\hline Lack_of_Corruption & & $\begin{array}{c}0.0034^{*} \\
(0.0019)\end{array}$ & \\
\hline Law_and_Order & & $\begin{array}{c}0.0002 \\
(0.0013)\end{array}$ & \\
\hline
\end{tabular}


Adj. R-squared

F-statistic

Prob(F-stat)
$26.3186 \%$

6.3778

0.0000
$91.4627 \%$

62.5150

0.0000
$85.2900 \%$

67.4295

0.0000 
Figure 1

\section{Cumulative Abnormal Returns around the General Strike Date}

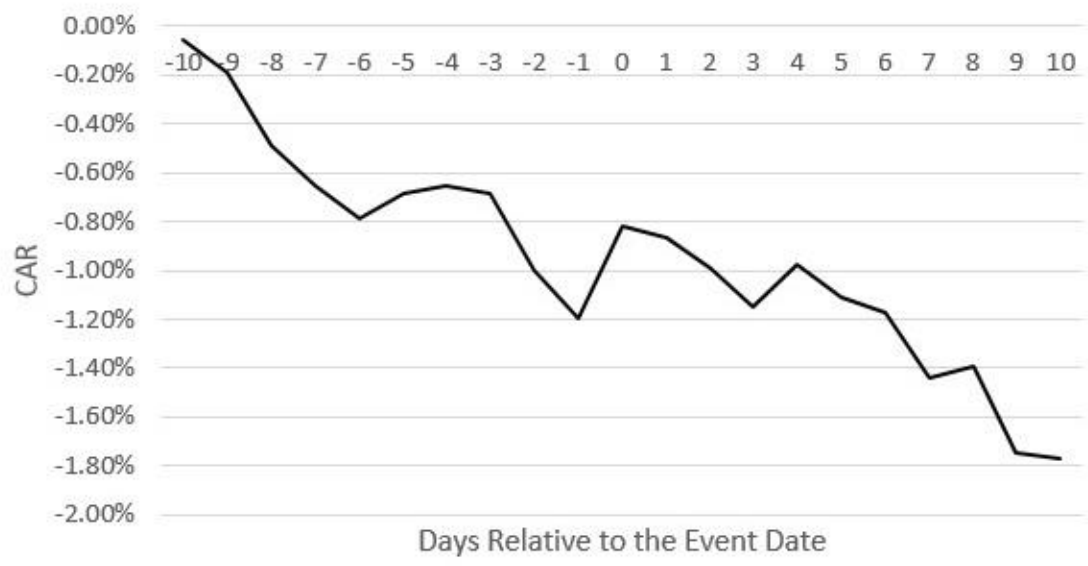

Note: This figure shows cumulative abnormal returns (CARs) in a symmetrical event window centred on the general strike starting date. The CAR estimates are based on a sample of 89 general strikes that occurred during the period spanning 2011 to 2015. 
Figure 2

Simulated Distribution of Mean Return under the Null Hypothesis of No General Strike

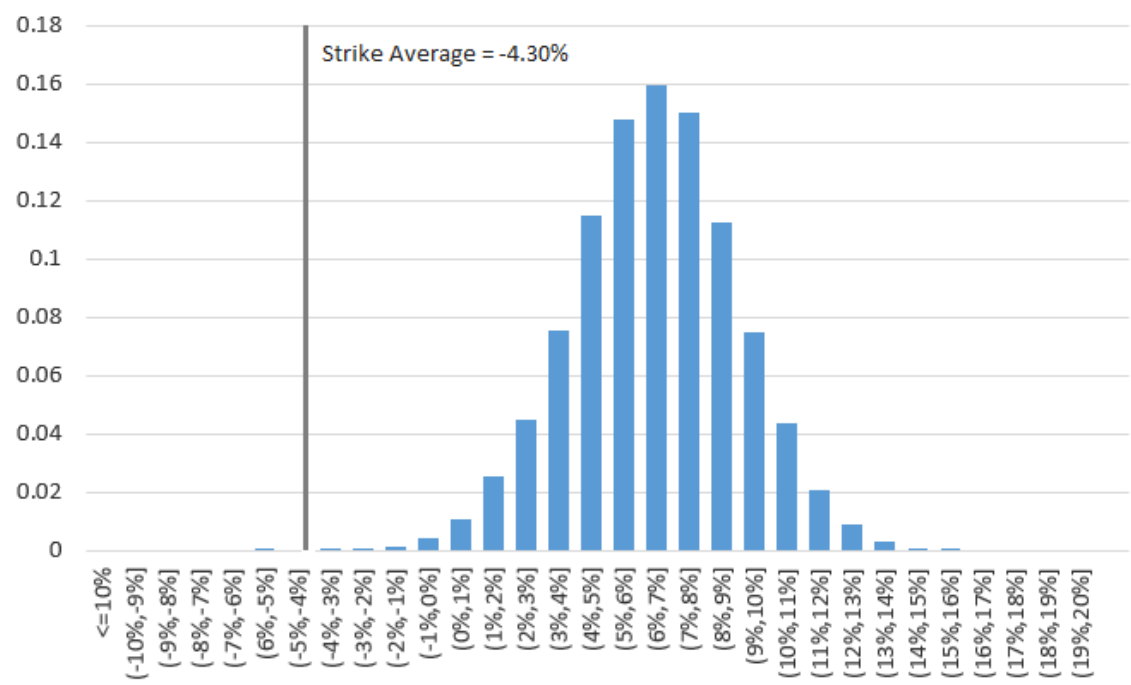

Note: The histogram above depicts empirical distribution of mean return under the assumption of no general strikes. It is based on a simulation with 10,000 iterations in which the general strike sample has been matched with a counterfactual sample. 